\title{
Potential of Various Immobilization Matrices in Heavy Metal Ions Removal Using Nostoclinckiabeads: A Comparative Study
}

\author{
Jyoti Rani ${ }^{1}$, C.P.Kaushik ${ }^{2}$ \\ ${ }^{1}$ Centre of Excellence for Energy and Environmental Studies, Deenbandhu Chhotu Ram University of Science \& \\ Technology, Murthal ,Sonepat-131039, Haryana, India. \\ ${ }^{2}$ Department of Environmental Science and Engineering, Guru Jambheshwar University of Science \\ \&Technology, Hisar, Haryana, India.
}

\begin{abstract}
This article reports the potential of removal of heavy metal ions of hexavalent chromium $\mathrm{Cr}(\mathrm{VI})$ and bivalent Cobalt Co (II) by different immobilization matrices containing dead cyanobacterial biomass of Nostoclinckia. Nostoclinckia was pre-treated by successive washes in distilled water, dried and then crushed to increase the surface area of biomass which was then immobilized in different immobilization matrices like Calcium alginate, polyvinyl alcohol alginate and polyvinyl alcohol alginate glutaraldehyde that was stable and easy to handle. The immobilized beads of Nostoclinckia was used to study the adsorption of metals (Cr VI \& Co II) from simulated wastewaters under varying range of contact time (5-180 minutes), $\mathrm{pH}(1-6)$ and initial metal ion concentration $(10-50 \mathrm{mg} / \mathrm{l})$ in a batch adsorption system. Experimental results showed that the different matrices pose impact on the different variable parameters like the optimum $\mathrm{pH}$ for biosorption of $\mathrm{Cr}(\mathrm{VI})$ ions was found to be 2.0 in alginate immobilized biomass while it was 4.0 polyvinyl alcohol alginate and polyvinyl alcohol alginate glutaraldehyde immobilized biomass. Similarly the maximum biosorption of Co (II) occurred at pH 3.0 in alginate biosorbent while it was 5 in polyvinyl alcohol alginate and polyvinyl alcohol alginate glutaraldehydebiosorbent. Similarly values of optimized contact times and initial metal ion concentrations were different for same biomass concentration immobilized in different matrices. From the results it can be concluded that the immobilization matrices affects the optimum values of different parameters in same conditions. Langmuir and Freundlich adsorption models were applied to describe the isotherms and isothermic constants. Freundlich model was fitted best in case of both metals. Alginate immobilized biomass was suited most for removal of hexavalent chromium $\left(R^{2}=0.992\right)$ while PVA-A is found to have very high adsorption capacity for Co (II) as shown by $\left(R^{2}=0.9978\right)$.
\end{abstract}

Keywords:Alginate, Heavy Metals, Immobilization, Nostoc, Polyvinyl alcohol

\section{Introduction}

The increase in gross domestic product has resulted in increase in pollution and degradation of natural resources. One of the most adversely affected resources is water as various industries are illegally disposing off their effluent either directly or indirectly via sewage system into natural water bodies. These industrial effluents have synthetic compounds, novel toxic chemicals, heavy metals and waste nuclear liquids etc. [1-2]. Contamination of natural streams by toxic heavy metal cations arise because of tannery, leather, electroplating, metal finishing, textiles, dying, paints etc. industries [3-4]. Several heavy metals are carcinogenic and mutagenic [5-6] and shows bioaccumulation through the food chain [7] as they are non-biodegradable hence their level must be reduced to acceptable level before discharging into water bodies [8]. Chromium exists usually in both trivalent and hexavalent forms in aqueous systems. Cr (III) is relatively insoluble and required by microorganisms in small quantities as an essential trace metal nutrient [9], while $\mathrm{Cr}$ (VI) is of great concern because of its toxicity. In animals $\mathrm{Cr}(\mathrm{VI})$ can cause respiratory problems, a lower ability to fight disease, birth defects, infertility and tumor formation. Due to environmental concern tolerance limit for $\mathrm{Cr}$ (VI) for discharge into inland surface waters is $0.1 \mathrm{mg} / \mathrm{L}$ and in potable water is $0.05 \mathrm{mg} / \mathrm{L}$ [10]. The Ministry of Environment and Forest (MoEF); Government of India has set minimal national standards (MINAS) of $0.1 \mathrm{mg} / \mathrm{L}$ for safe discharge of effluent containing $\mathrm{Cr}$ (VI) in surface water [11]. After chromium one another metal Cobalt is also of great concern as it is used in many alloys and super-alloys for parts in gas turbine aircraft engines, corrosion resistant alloys, high-speed steels, cemented carbides, in magnets and magnetic recording media, as catalysts for the petroleum and chemical industries, as drying agents for paints and inks. Cobalt is an important constituent of vitamin B12, and is used for treatment of anemia because it stimulates the production of red blood cells. Radioactive cobalt isotopes are also used to destroy tumor in cancer patients. However too high concentration of cobalt may results in asthma, weight loss, vomiting, respiratory hyper sensitivity, dermatitis, nausea, vision problems, heart problems and thyroid damage [12]. Nowadays, there are many methods for metals removal such as chemical coagulation, flocculation, chemical oxidation, photochemical degradation, membrane filtration, ion exchange, gamma ray irradiation, solvent extraction, hydrolysis, aerobic and anaerobic biological degradation 
but their overall cost, incomplete metal removal; intensive energy requirement, regeneration problem and secondary pollutant/ toxic sludge generation limit their usages [13-15]. Physico-chemical processes result in transfer of the pollutants from one system to another without degrading it and is highly expensive if the contaminant concentration are in the range of $10-100 \mathrm{mg} / \mathrm{L}$ [16]. Considering all these points in the view biosorption could be considered as possible alternative technique for heavy metals removal as it is economically viable and environmentally friendly [17]. Microbial population growing in contaminated environment show adaptation to the toxic pollutants like heavy metals and become metal resistant [18]. Micro-organisms uptakes metal either actively (bioaccumulation) or passively (biosorption) [19-23]. Huge work has been carried out on removal of heavy metals by using microorganisms like algae, fungi and bacteria but little attention has been paid to investigate the effect of operating variables on the metals ion sorption characteristic of microorganisms immobilized in different immobilization matrices. Micro-organisms like fungi, bacteria and algae are available in abundant and can grow easily in contaminated environment, have been studied to see the remediation of heavy metals by live, dead and immobilized biomass [1-2,8,24-28]. Immobilized microorganisms are more suitable for industrial application as compared to free biomass because of better mechanical strength, chemical stability, and repeated adsorption- desorption characteristics [29-30]. Algal biosorbents for metals removal from aqueous solution are in use for quite some time in the form of both live and dead biomass [31-32].

The present study was undertaken with an objective to assess and optimize the role of immobilization matrices in metal ions sorption ability by dead biomass of caynobacteriumNostoclinckia. Different parameters were optimized for their removal by immobilized biomass in different immobilization matrices and kinetic models were also applied on biomass immobilized in different matrices to compare the efficiency of matrices to remove the metal ions.

\subsection{Alginate}

Alginate is natural nontoxic, biodegradable and biocompatible polysaccharide distributed in brown seaweeds. It is a water-soluble most versatile biopolymers used in a wide range of applications as stabilizing agent. Hydrated alginate develops into gel when exposed to calcium ions. Calcium alginate gel shown in Fig 1.1 is used in encapsulating various active compounds. As a consequence, alginate gels have been exploited in food applications for the encapsulation of aroma and essential oils [33-34].

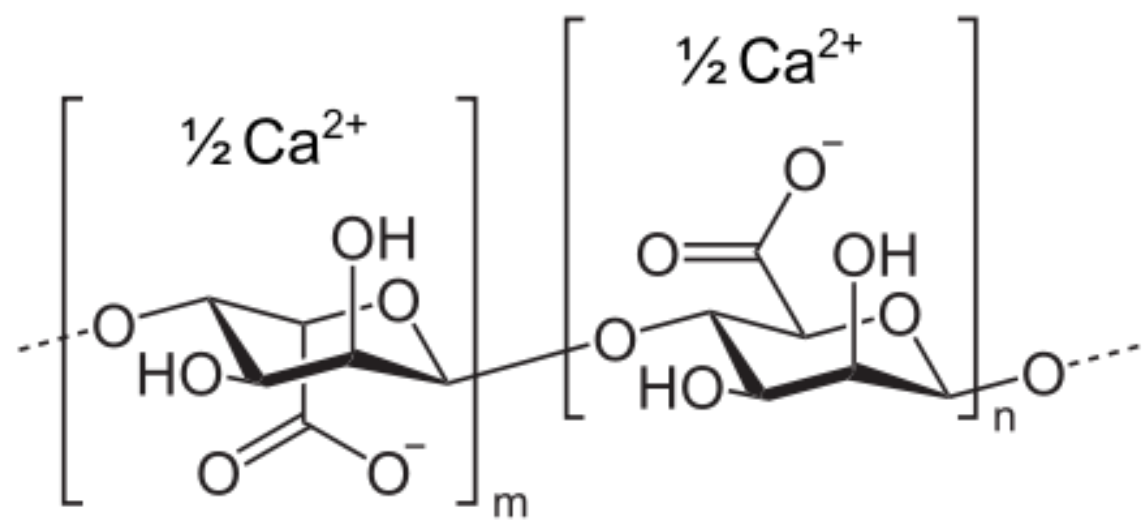

Figure1.1 Chemical Structure Of Calcium Alginate [35]

\subsection{Polyvinyl Alcohol}

Poly Vinyl Alcohol (PVA) Fig. 1.2 was first prepared by Hermann and Haehnel in 1924 by hydrolyzing polyvinyl acetate in ethanol with potassium hydroxide. Polyvinyl alcohol is an odorless and tasteless, translucent, white or cream colored granular powder. [36]

It is a non-toxic, hydrophilic, synthetic polymer capable of forming hydrogel by chemical cross-linking [37] or freeze-thawing [38]. PVA matrix produced upon freeze-thaw cycles has mainly been investigated for biological applications. These gels are non-toxic and have a high level of mechanical stability [39].

The physical characteristics and its specific functional uses depend on the degree of polymerization and the degree of hydrolysis. When the PVA is dissolved in water, the vinyl alcohol units link up to form chains of about 2,000 units. It is reported that PVA is a good matrix to promote the formation of three-dimensional structure of the beads, strengthen the beads' stiffness and improve the DO inside the beads [40]. 


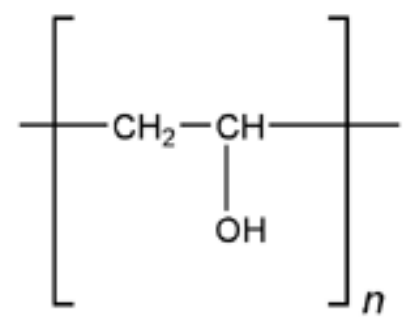

Figure. 1.2 Structure Of Polyvinyl Alcohol

\subsection{Glutaraldehyde}

Glutaraldehyde is an organic compound, pungent, colorless oily liquid, with the formula $\mathrm{CH}_{2}\left(\mathrm{CH}_{2} \mathrm{CHO}\right)_{2}$ shown in Fig. 1.3 and is used to disinfect medical, dental equipment, industrial water treatment and as a preservative.

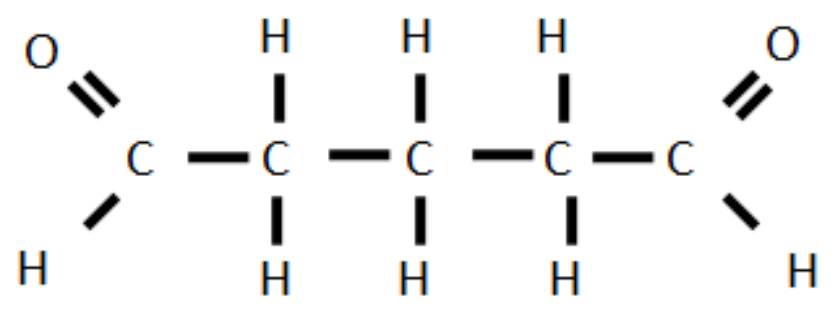

Figure 1.3 Glutaraldehyde [41]

\subsection{Preparation Of Biomass}

\section{Materials And Methods}

Nostoclinckia a filamentous cyanobacteria isolated from contaminated site was taken from department of Environment Science and Engineering, Guru Jambheshwar University of Science and Technology, Hisar, and cultivated in BG-11 medium for 7 days after which it was washed thrice with distilled water and dried in an oven at $80^{\circ} \mathrm{C}$ for one day. It was then finely powdered to increase the surface area of biomass.

\subsection{Immobilization Of Biomass}

\subsubsection{Alginate Gel}

Cyanobacterial suspension (7days old culture containing $0.1 \mathrm{~g}$ dry weight) and $4 \%$ sodium alginate were mixed and suspension was dropped into $2 \%$ calcium chloride solution via a syringe $(5 \mathrm{ml})$ to form the small beads $(3 \mathrm{~mm} \pm 0.1)$. The beads were subjected at $4^{0} \mathrm{C}$ temperature to get polymerize.

\subsubsection{Polyvinyl Alcohol Alginate}

PVA-alginate slurry $(2: 1 \%, \mathrm{~W} / \mathrm{V})$ was prepared and biomass powder $0.1 \mathrm{~g}$ dry weight of N.linckia was added and stirred. Beads were prepared in $2 \% \mathrm{CaCl}_{2}$ with the help of $5 \mathrm{ml}$ syringe. After $6 \mathrm{hr}$ of curing, the beads were subjected to three cycles of freezing $\left(<2^{0} \mathrm{C}\right)$ and thawing $\left(30 \pm 2^{0} \mathrm{C}\right)$ to get spherical beads.

\subsubsection{Polyvinyl Alcohol Alginate Glutaraldehyde}

PVA-alginate slurry $(2: 1 \%$, W/V) was prepared and biomass powdered $0.1 \mathrm{~g}$ dry weight of N.linckiawas added and stirred. Add glutaraldehyde into the slurry in the same amount as that of alginate. Give gentle shaking for 10 minutes. PVA-alginate-glutaraldehyde-biomass slurry was then extruded into $2 \% \mathrm{CaCl}_{2}$ solution via a syringe to form small beads. The beads were subjected at $4^{0} \mathrm{C}$ temperature to get polymerize.

\subsection{Metal Ions Solution Preparation}

Chromium solution was prepared by dissolving 2.828 grams of potassium dichromate (AR Grade) in deionized water and diluted to $1000 \mathrm{ml}$ in order to get $1000 \mathrm{mg} / \mathrm{l}$ hexavalent chromium solution. Different concentrations for the experiments were prepared using this stock solution.

$1000 \mathrm{mg} / \mathrm{l}$ bivalent cobalt solution was prepared by dissolving 3.104 grams of cobalt (II) nitrate (AR Grade) in $1000 \mathrm{~mL}$ deionized water. This stock solution was used for further dilution for the experiments. The $\mathrm{pH}$ of the solution was adjusted using either $0.1 \mathrm{M} \mathrm{HNO}_{3}$ or $0.1 \mathrm{M} \mathrm{NaOH}$ solutions. 


\subsection{Optimization Studies:}

\subsubsection{Contact Time Optimization}

$100 \mathrm{ml}$ culture solution containing $20 \mathrm{mg} / \mathrm{l}$ metals ion concentration was taken in triplicate and $\mathrm{pH}$ was adjusted in between 8-9. Beads containing immobilized biomass were transferred to $250 \mathrm{~mL}$ Erlenmeyer flasks containing heavy metals solutions. The flask were shaken at 120 oscillations per minute at light intensity of 3000lux and at constant temp $28 \pm 2^{\circ} \mathrm{C}$ for different time intervals i.e. 5,10,15,30,45,60,90,120,150 and 180 minutes. The remaining metal concentrations were measured on AAS (atomic absorption spectrophotometer Simazdu 6300AA).

\subsection{2 pH Optimization}

$100 \mathrm{ml}$ culture solution containing $20 \mathrm{mg} / \mathrm{l}$ buffered metal solutions with $\mathrm{pH}$ ranging from 1 to $6(\mathrm{pH} 1$, $2,3,4,5$ and 6) were used at optimum contact time as determined from the previous experiments. Beads containing immobilized biomass were added to each flask and the solutions were shaken at constant temperature $28 \pm 2^{\circ} \mathrm{C}$ and speed 120 oscillations per minutes in orbital shaker.

\subsubsection{Optimization of Initial Metal Ions}

After optimization of $\mathrm{pH}$ and contact time from the above experiments, the initial concentrations of metal ions more suitable for removal by the Nostoc were estimated.

The beads containing immobilized biomass were added to $100 \mathrm{ml}$ solution of culture medium containing 10-50 mg/l metal ions concentrations at optimum $\mathrm{pH}$ and contact time. The flasks were shaken at constant temperature $28 \pm 2^{\circ} \mathrm{C}$ and speed 120 oscillations per minutes in orbital shaker.

\subsection{BiosorptionStudies}

Biosorption studies were conducted in batch mode to evaluate the effect of $\mathrm{pH}$ (1-6), contact time (5180 minutes) and initial metal ion concentration $(10-50 \mathrm{mg} / \mathrm{l})$ on removal of $\mathrm{Cr}$ (VI) and Co (II) from their respective synthetic solution using immobilized biomass. All biosorption experiments were conducted in triplicates using conical flask $(250 \mathrm{ml})$ on an incubator cum shaker $(120 \mathrm{rpm})$ at $28 \pm 2^{\circ} \mathrm{C}$. The amount of metal uptake $(\mathrm{mg} / \mathrm{g})$ was obtained by using equation (1).

$q e=\frac{\left(C_{0}-\text { Ce }\right) V}{W}$

Where qe is equilibrium uptake $(\mathrm{mg} / \mathrm{g})$; Co is initial metal ion concentration $(\mathrm{mg} / \mathrm{l})$; Ce is equilibrium metal ion concentration ( $\mathrm{mg} / \mathrm{l})$; $\mathrm{V}$ is the volume of the metal solution $(\mathrm{l}) ; \mathrm{W}$ is the mass of the sorbent $(\mathrm{g})$.

\subsection{Adsorption Isotherms:} isotherms

The biosorption data obtained for the $\mathrm{Cr}$ (VI) and Co (II) was analyzed using Langmuir and Freundlich

2.6.1 Langmuir's Isotherm Model[42] is valid for monolayer adsorption onto a surface containing a finite number of identical sites, which is represented as equation (2).

$$
\mathrm{Ce} / \mathrm{qe}=1 / \mathrm{Qob}+\mathrm{Ce} / \mathrm{Qo}
$$

Where qe is the adsorbed at equilibrium (mg/g); Ce is the equilibrium concentration (mg/l); Qo and b are the Langmuir constants.

2.6.2 The Freundlich Equation[43] proposes an empirical model that is based on the sorption on heterogenous surface and is represented as equation (3).

$\log \mathrm{x} / \mathrm{m}=\log \mathrm{k}+1 / \mathrm{nlog} \mathrm{Ce}$

Where $\mathrm{k}(\mathrm{mg} / \mathrm{g})$ shows adsorption capacity and $\mathrm{n}$ represents intensity of adsorption and are known as Freundlich isotherms constants; Ce is the equilibrium concentration $(\mathrm{mg} / \mathrm{l}) ; \mathrm{x} / \mathrm{m}$ is the amount of metal ions adsorbed per unit mass of adsorbent $(\mathrm{mg} / \mathrm{g})$ and $\mathrm{m}$ is the adsorbent dose $(\mathrm{g} / \mathrm{l})$.

\subsection{Contact Time}

\section{Results and Discussion}

The effect of contact time on removal of metal ions have been shown in Fig. 3.1 a \& 3.1 b. Cr (VI) adsorption onto the beads increased sharply with agitation time upto 20 minutes and then equilibrium was attained after 90 minutes, it gradually decreased and remained constant till 180 minutes. The rapid initial removal was likely due to extracellular binding and slow sorption after equilibrium may be due to intracellular binding which tales more time due to mass transfer problems [44-46]. Maximum metal ion removal of $86.6 \%$ 
occurred at 90 minutes of contact time for biomass immobilized in alginate, 45 minutes for PVA-alginate $(86.6 \%)$ and 150 minutes in PVA-alginate-glutaraldehyde $(86.5 \%)$ matrices. From the results it can be concluded that maximum percentage removal is nearly same by immobilized biomass in all the three matrices at different agitation times. Agitation time is very less in case of biomass immobilized in polyvinyl alcohol alginate which reveals that it can remove the same amount of $\mathrm{Cr}$ (VI) in very less time as compared to other two matrices.

Kiran et al., [47] have also reported that the maximum removal of Cr (VI) by Lyngbyaputealis HH-15 occurred at 120 minutes of contact time with similar biosorption pattern. Initial rapid sorption of Cr (VI) suggests the involvement of a passive process of metal binding on algal surface that is followed by a gradual and slow state which is likely to be associated with some active energy mediated process. Similar results were obtained byAkhtar[48] and Mohanty[49] that the maximum removal of chromium occurred in the initial stage which gradually decreased and remained almost constant after an optimum period.

It was also observed that the adsorption got slowdown in later stages because initially a large number of vacant surface sites may be available for adsorption and after some time the remaining vacant sites are difficult to occupy due to repulsive forces between the solute molecules of the solid and bulk phase [50-51]

Kiran et al, (2007) [31] observed 60-75\% removal of Cr (VI) by immobilized L. putealiswhile in the present study the removal of $\mathrm{Cr}$ (VI) is much higher lying between $85-86 \%$ by Nostoclinckia immobilized in all the three matrices. Kumar [52] have also obtained similar results for removal of $\mathrm{Cr}$ (VI) byPenicilliumjanthinellm.

Biosorption of cobalt (II) metal showed a rapid exponential phase upto the first 60 minutes showing 94-96\% removal by algal beads, thereafter it increased slowly and became constant at contact time of 120 minutes in case of biomass immobilized in PVA-alginate $(97.5 \%$, Fig.3.1 b) as well as PVA-alginateglutaraldehyde $(97.7 \%$ ) while in case of biomass immobilized in alginate maximum removal of cobalt occurred at 90 minutes of contact time Fig. 3.1 a (94.7\%) after which it decreased which show leakage of adsorbed metal ions and then became costant. Similar pattern of metal biosorption have been observed for other metals also [5354].

Removal was maximum (97.69\%) in PVA- alginate-glutaraldehyde immobilized cells as compared to biomass immobilized in other two matrices. Ajjabi[55] obtained biosorption rate for $\mathrm{Cu}^{2+}$ and $\mathrm{Zn}^{2+}$ by ChaetomorphaLinum which was fast and most of the process was completed within 120 min. Similarly Garnham[56] showed that the uptake of the Co was maximum at agitation time of $2 \mathrm{~h}$ using immobilized biomass of C.salina.

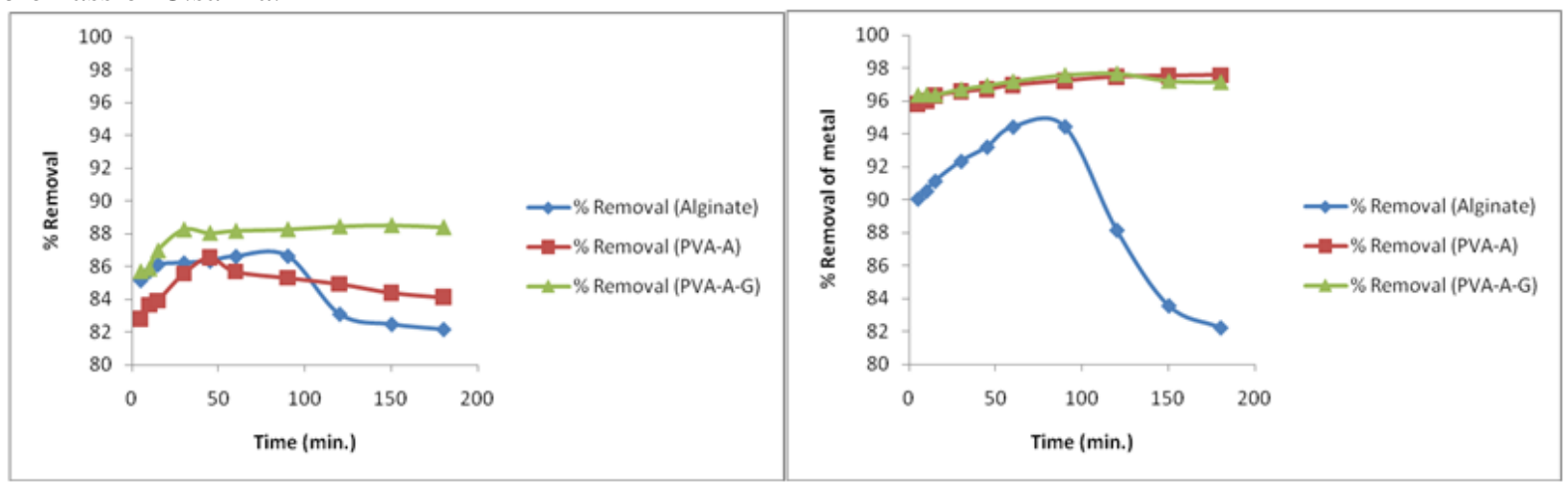

Figure 3.1a Effect Of Contact Time On \% Removal Of Cr(VI) And 3.1 B \% Removal Of Co(II) By

\subsection{Effect of $\mathrm{pH}$}

Nostoclinckiaimmobilzed In Three Different Matrices

$\mathrm{PH}$ affect the percentage of ionization of functional groups present on cell wall of biomass [57-59]. The effect of $\mathrm{pH}$ on biosorption has been shown in fig 3.2 a \& $3.2 \mathrm{~b}$. It was observed that maximum removal of chromium occurred at $\mathrm{pH} 2$ for biomass immobilized in alginate and $\mathrm{pH} 4$ for other two matrices.

In the range of $\mathrm{pH} 2.0$ to $6.0, \mathrm{HCrO}_{4}{ }^{-}$and $\mathrm{Cr}_{2} \mathrm{O}_{7}{ }^{-}$ions are in equilibrium whereas, at lower $\mathrm{pH}$ there is formation of more polymerized chromium oxide species such as $\mathrm{Cr}_{3} \mathrm{O}_{10}{ }^{2-}$ and $\mathrm{Cr}_{4} \mathrm{O}_{13}{ }^{2-}$ [60] which results in decrease in $\mathrm{Cr}(\mathrm{VI})$ removal. As the $\mathrm{pH}$ of the solution increases, the number of negatively charged sites increased and positively charged sites decreased. A negatively charged surface site on the adsorbent does not favour the adsorption of anions due to electrostatic repulsion. In acidic medium the equilibrium is shown by equation (4) and (5) as follows:

$\mathrm{HCr}_{2} \mathrm{O}_{7} \longrightarrow \mathrm{H}^{+}+\mathrm{Cr}_{2} \mathrm{O}_{7}^{-}$

$\mathrm{H}_{2} \mathrm{CrO}_{4} \longrightarrow \mathrm{H}^{+}+\mathrm{HCrO}_{4}^{-}$
In alkaline medium the equilibrium is as represented by equations (6) and (7) as follows: 
$\mathrm{Cr}_{2} \mathrm{O}_{7}^{2-}+\mathrm{OH}^{-} \longrightarrow \mathrm{HCrO}_{4}^{-}+\mathrm{CrO}_{4}^{2-}$

$\mathrm{HCrO}_{4}^{-}+\mathrm{OH}^{-} \longrightarrow \mathrm{CrO}_{4}{ }^{2-}+\mathrm{H}_{2} \mathrm{O}$

The low chromium biosorption at $\mathrm{pH} 2$ may be explained on the basis of active sites being protonated, resulting in a competition between protons and chromium for occupancy of the binding sites. Similar trends in the sorption data have previously been reported for Chromium sorbing onto seaweed biomass of Sargassum[61] and Eckloniaspecies.[62]
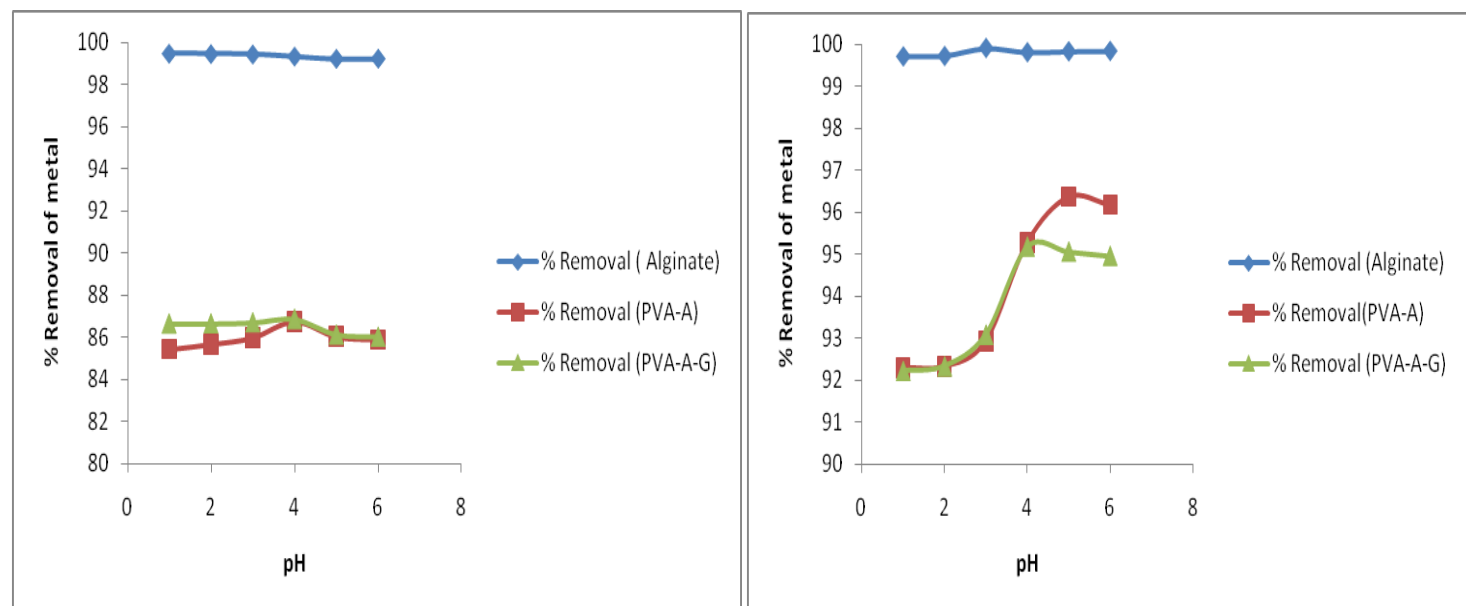

Figure 3.2a Effect of solution $\mathrm{pH}$ on the \% removal of $\mathrm{Cr}$ (VI) and 3.2 b \% removal of Co(II) by Nostoclinckiaimmobilized in different matrices

Gardea-Torresdey[63] observed the same value of $\mathrm{pH} 2$ for removal of chromium (VI) by Synechococcus sp. PCC 7942. Similar results were obtained by Tiwari[64] in batch experiments for sorption and desorption of $\mathrm{Cr}$ (VI) using Mucorhiemalis. Dacera[65] investigated removal of $\mathrm{Cr}$ (VI) and $\mathrm{Zn}$ (II) and Ni (II) by A. niger was maximum at $\mathrm{pH}$ 4. Similar results were obtained by Kumar [66] in biosorption process for removal of $\mathrm{Cr}$ (VI), $\mathrm{Ni}$ (II) and Zn (II) ions by immobilized bacterial biomass sp. Bacillus brevis.

Cobalt (II) Metal removal varied at different $\mathrm{pH}$ levels ranging from 2 to 5. It was observed that maximum removal of cobalt was at $\mathrm{pH} 3$ for biomass immobilized in alginate and $\mathrm{pH} 5$ for biomass immobilized in other two matrices.

At $\mathrm{pH}$ around 5, Co (II) adsorption capacity leveled off because at low $\mathrm{pH}$ values, the concentration of hydrogen protons in the solution far exceeds, these protons competed with the metal ions in forming a bond with the active sites (the functional groups) on the surface of the algae, leaving the metals ions free in solution. These bonded active sites thereafter became saturated and was inaccessible to other cations. When the $\mathrm{pH}$ was increased, the competing effect of hydrogen protons decreased and the positively charged metals ions took up the free binding sites. Hence, an increase in the sorption capacity or removal efficiency could be observed. The decrease in sorption efficiency at $\mathrm{pH}>5$ could be due to the formation of anionic hydroxide complexes and their competition with active sites. These results were in good agreement with findings of previous researchers [6773] observed themaximumCo (II) removal efficiency occurred at $\mathrm{pH}$ 2. Jose [74]obtained the sharpest increase in heavy metal sorption between $\mathrm{pH} 2$ and 3, while around $\mathrm{pH} 4.5$ a plateau is reached. Beyond $\mathrm{pH} 5$ precipitation of heavy metals occur which show the suitability of biosorbent for treatment of acidic waste water.Yalçın[75] investigated maximum biosorption capacity of Cladophoraglomerata at $\mathrm{pH} 5.0$ for $\mathrm{Cu}$ (II) and at $\mathrm{pH} 4.0$ for $\mathrm{Pb}$ (II) metal ions.

\subsection{Initial Metal Ions Concentration}

Initial metal ions concentration provides important driving force to overcome all mass transfer resistance of the metal between aqueous solution and the solid phase [76-77]. The effect of initial metal ion concentration on Co (II) and Cr (VI) uptake capacity of immobilized Nostoclinckia biomass was studied at optimized contact time and $\mathrm{pH}$ at varying concentrations of metals ions from 10 to $50 \mathrm{mg} / \mathrm{L}$ as shown in Fig 3.3 a \& 3.3 b. In alginate immobilized cells percent removal of metal ions increased as the initial metal ions concentration increased from 10 to $30 \mathrm{mg} / \mathrm{l}$ and then decreased from 30 to $50 \mathrm{mg} / \mathrm{l}$. The maximum removal occurred at $30 \mathrm{mg} / \mathrm{l}$ in alginate matrix for hexavalent chromium as well as bivalent cobalt and at $10 \mathrm{mg} / \mathrm{L}$ by polyvinyl alcohol alginate and polyvinyl alcohol alginate glutaraldehyde immobilized cells for chromium (VI) after that it decreased steadily. Removal of cobalt (II) was maximum at $20 \mathrm{mg} / \mathrm{L}$ for biomass immobilized in polyvinyl alcohol alginate as well as polyvinyl alcohol alginate glutaraldehyde then decreased from 20 to 50 $\mathrm{mg} / \mathrm{L}$. 
Similarly Kamra et al, (2007) [32] showed the maximum biosorption capacity of alginate immobilized Nostoccalcicola HH-12 and Chroococcus sp.HH-11 occurred at initial chromium concentration of $20 \mathrm{mg} / \mathrm{l}$ for both the strains. Kumar [66] obtained the maximum biosorption of $\mathrm{Cr}$ (VI) at $35 \mathrm{mg} / \mathrm{l}$ initial metal ion concentration inbiosorption process for removal of $\mathrm{Cr}$ (VI), Ni (II) and Zn (II) ions by immobilized bacterial biomass sp.Bacillus brevis. The optimum biosorption of $\mathrm{Cr}(\mathrm{VI})$ occurred at initial chromium concentration of $20 \mathrm{mg} / \mathrm{l}$. Simiarly Kumar [78] showed that the maximum removal of heavy metal using fungal biomass occurred at a concentration of $30 \mathrm{mg} / 1$.

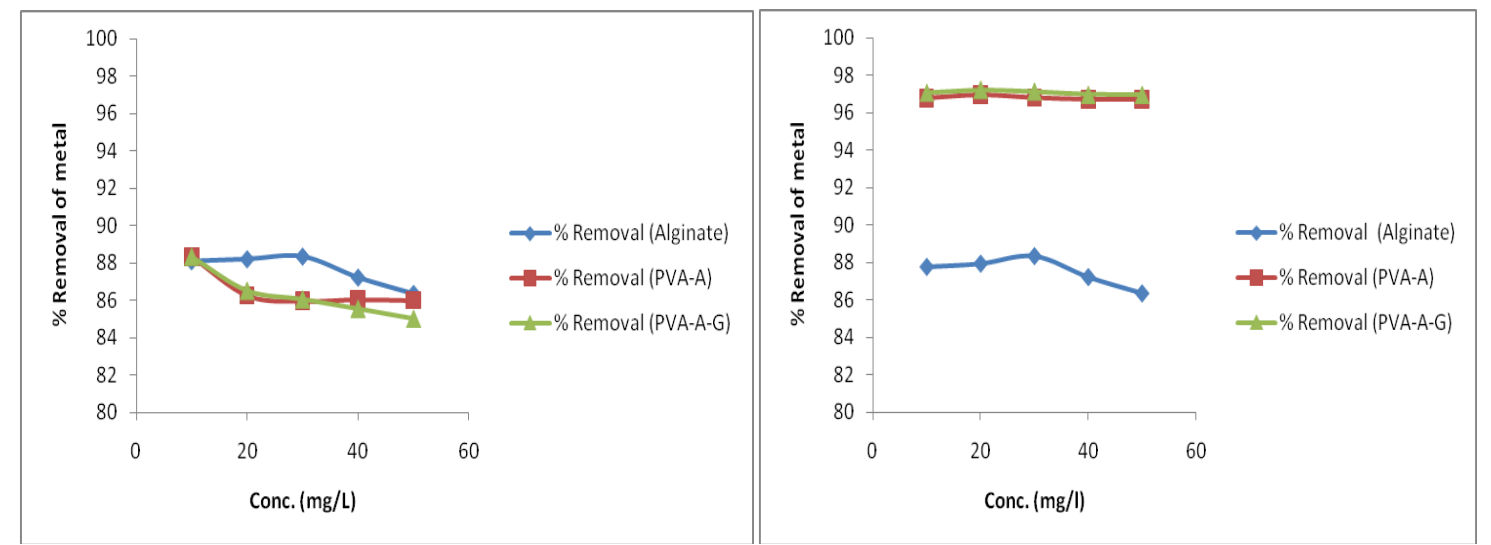

Figure 3.3 a Effect of initial metal concentration Cr(VI) and 3.3 b (CoII) on biosorption potential of Nostoclinckiaimmobilized in different matrices

\subsection{Biosorption Studies}

Freundlich isotherms was best suited for $\mathrm{Cr}(\mathrm{VI})$ as well as $\mathrm{Co}(\mathrm{II})$ biosorption. Alginate immobilized biomass was found to be best suited for the removal of $\mathrm{Cr}$ (VI) according to adsorption isotherms while Polyvinyl alcohol alginate was good for the removal of $\mathrm{Co}(\mathrm{II})$. For hexavalent higher value of $\mathrm{K}_{\mathrm{f}}(7.57)$ and $\mathrm{n}=1.074$ indicates high adsorption capacity of biomass per unit weight which is much higher than other biosorbents like Spirogyra sp. (3.75mg/g) [79] Lyngbya sp. $(6.42,1.49)$ [31] and high intensity of adsorption. High values of correlation coefficient $\left(\mathrm{R}^{2}=0.9926\right)$ also supports the suitability of freundlich model.

For cobalt removal the values of $\mathrm{K}_{\mathrm{f}}$ and $\mathrm{n}$ are 30.47 and 1.006 respectively which show the adsorption capacity of biomass per unit of weight and high intensity of adsorption [80]. The situation $n>1$ is most common may be due to a distribution of surface sites or any factor that causes a decrease in interaction of adsorbent adsorbate with increasing surface density [81] and the values ofn lie between 1 and 10 indicates favorable adsorption

[82-84]. In the present study, since $n$ lies between 1 and 10 it indicates the physical adsorption of metal ions onto matrices.

Freundlich model is suited which indicate the heterogenous nature of biosorbent surface [85-86]and hence it show multilayer adsorption of metal ions on the surface of immobilized biomass.

\section{Conclusion}

Three entrapped supports were chosen to immobilize Nostoclinckia. The result of the study revealed that change in solidification material affect the optimum value of the various parameters. Based on the experimental data the following conclusions were drawn:

1. The time required to reach equilibrium for hexavalent chromium removal was found to be 90 minutes in alginate, 45 minutes in PVA- Alginate and 150 minutes in PVA-A-Glutaraldehyde immobilized biomass with $86.6 \%$ removal efficicency. Cobalt (II) biosorption was reached at equilibrium at 90minutes in alginate, and 120 minutes in other two matrices with 94.5 to $97.7 \%$ removal efficiency.

2. Alginate immobilized biomass showed the maximum removal of chromium (VI) at $\mathrm{pH} 2$ and cobalt at $\mathrm{pH} 3$ while PVA-Alginate and PVA-A-glutaraldehyde removed the maximum chromium (VI) metal ions at $\mathrm{pH} 4$ and Cobalt (II) at pH 5.

3. Alginate immobilized Nostoc was found to be more efficient than PVA-Alginate and PVA-A-Gltaraldehyde in removing high metal ions concentration up to $30 \mathrm{mg} / \mathrm{L}$ in both chromium (VI) and cobalt (II).

4. Alginate matrix was found to be best suited for $\mathrm{Cr}$ (VI) removal and PVA-Alginate \& PVA-AGlutaraldhyde were best for bio sorption of cobalt(II).

5. Addition of glutaraldhyde to PVA-Alginate does not change the optimization value of parameters up to a large difference. 


\section{References}

[1]. K.K. Kumar, M.K. Prasad, G.V.S. Sarma, and Ch. V.R.Murthy, Removal of Cd (II) from Aqueous Solution using Immobilized RhizomucorTauricus, Journal of Microbial \& Biochemical Technology, 1(1), 2009, 15-21.

[2]. M. J. Rani, B. Hemambika, J. Hemapriya and V. R. Kannan, Comparative assessment of heavy metal removal by immobilized and dead bacterial cells: A biosorption approach, African Journal of Environmental Science and Technology, 4(2), 2010, 77-83.

[3]. M. M. Alves, C. G. G.Ceca, R.G.Carvalho, J. M. De Castanheira, M. C. S. Periera and L.A.T.vasconcelos, Chromium removal in tannery wastewaters polishing by pinussylvestris bark, Wat. Res.,27, 1993,1333-1338,

[4]. Z. Aksu, and G.Do"nmez, Binary biosorption of cadmium(II) and nickel(II) onto dried Chlorellavulgaris: co-ion effect on monocomponent isotherm parameters, Proc. Biochem., 41, 2006, 860-868.

[5]. B.J. Alloway, Heavy metal in soils, second edition. (Chapman and Hall, London 1995).

[6]. L, Diels, N. Van der Lelie, and L. Bastiaens, New development in treatment of heavy metalcontaminated soils. Rev. Environ. Sci. Biotechnol., 1, 2002, 75-82.

[7]. H. Doshi, A. Ray, and I.L.Kothari, Biosorption of cadmium by live and dead Spirulina: IRspectroscopic, kinetics and SEM studies. Curr.Microbiol.,54,2007,213-218.

[8]. M.A. Hanif and H.N. Bhatti, Bioremediation of nickel from wastewater using immobilizedPhanerochaetechyrsosporium biomass, International Journal of Chemical and Biochemical Sciences, 2, 2012, 54-59.

[9]. G.Saner, Chromium in Nutrition and Diesease, (Alan R Liss Inc., New York 1980).

[10]. EPA (Environmental Protection Agency, Environmental Pollution Control Alternatives) 1990.EPA/625/5-90/025, EPA/625/489/023, Cincinnati, US.

[11]. MINAS, Pollution control acts, rules, and notification there under Central Pollution ControlBoard, Ministry of Environment and Forests, Government of India, New Delhi, 2001.

[12]. Http://www.lenntech.com/periodic/elements/Co.htm.

[13]. T.V.N. Padmesh, K. Vijayraghavan, G. Sekaran, and M.velan, Biosorption of acid blue 15 usingfresh water macroalgaAzollafiliculuides: Batch \& column studies. Dyes \&pigm., 7, 2006, 77-82.

[14]. K. Kadirvelu, K. Thamaraiselvi, and C. Namasivayam, Adsorption of nickel(II) from aqueoussolution onto activated carbon prepared from coir pith. Sep. Purif. Technol., 24, 2001,477-505.

[15]. K. Kadirvelu, P. Senthilkumar, K. Thamaraiselvi, and V. Subburam , Activated carbon preparedfrom biomass as adsorbent: elimination of $\mathrm{Ni}(\mathrm{II})$ from aqueous solution. Bioresour. Technol., 81,2002, 87-90.

[16]. J.B. Patterson, Waste water treatment. (Science Publishers, 1977)

[17]. B. Volesky, Sorption and Biosorption. (BV Sorbex Inc., 1999)

[18]. B. Prasenjit, and S. Sumathi, Uptake of chromium by Aspergillusfoetidus. J. Mater. Cycles Waste Manage., 7, 2005, 88-92.

[19]. E.S. Shumate, and W.G. Strandberg, Accumulation of metals by microbial cells. Compr.Biotechnol., 13,1985, $235-247$.

[20]. M.Y.J.H. Anders and C.J. Hubert, Bacterial biosorption and retention of thorium and uranylcations by mycobacterium smegmatis. J. Radio Anal. Nucl.Lett., 166, 1992, 431-440.

[21]. E. Fourest, and C.J. Roux, Heavy metal biosorption by fungal mycilial by-products: mechanisms and influence of pH.Appl. Microbiol. Biotechnol., 37(3), 1992, 399-403.

[22]. H. Hussein, R. Krull, S.I. Abou el-ela, D.C. Hempel, Interaction of the different heavy metal ions with immobilized bacterial culture degrading xenobiotic wastewater compounds. In: Conference Proceedings: Int. Water Assoc. World Water Conf., Berlin, Germany, 2001.

[23]. H. Hussein, S. Farag, and H. Moawad, Isolation and characterisation of Pseudomonas resistant to heavy metals contaminants.Arab J. Biotechnol., 7, 2003,13-22.

[24]. B. Hemambika, M. Johncy Rani and V. Rajesh Kannan, Biosorption of heavy metals by immobilized and dead fungal cells: A comparative assessment, Journal of Ecology and the Natural Environment, 3(5), 2011, 168-175.

[25]. M. Sharma, N. Rani, A. Kamra, A. Kaushik and K. Bala, Growth, Exopolymer Production and Metal Bioremoval by Nostocpunctiforme in Na+ And Cr (Vi) Spiked Medium, Journal of Environmental Research and Development 4(2), 2009, $372-379$.

[26]. I. Kim , M. Lee, and S. Wang, Heavy metal removal in ground water originating from acid mine drainage using dead Bacillus drentensis sp. Immobilized in polysulfone polymer, Journal of Environmental Management, 146, 2014, 568-574.

[27]. A. Kaushik, M. Sharma, and C.P. Kaushik, Integrating photobiological hydrogen production with dye-metal bioremoval from simulated textile wastewater, BioresourceTechnology, 102, 2011, 9957-9964.

[28]. M. Sharma , A. Kaushik, and C.P. Kaushik, Prolonged hydrogen production by Nostoc in photobioreactor and multi-stage use of the biological waste for column biosorption of some dyes and metals, biomass and bioenergy, 54, 2013, 27-35.

[29]. M. Tsezos, R.G.L. Mccready, and J.P. Bell,The continuous recovery of uranium from biologically leached solutions using immobilized biomass. BiotechnolBioeng 34, 1989, 10-17.

[30]. J.R. Lloyd, C.L. Harding, L.E. Macaskie, Tc (vii) reduction and accumulation by immobilized cells of Escherichia coli. BiotechnolBioeng 55, 1997, 505-510.

[31]. K. Bala, A. Kaushik, and C.P. Kaushik, Biosorption of $\mathrm{Cr}(\mathrm{VI})$ by native isolate of Lyngbyaputealis (HH-15) in presence of salts, J.Haz.mat.,141, 2007, 662-667.

[32]. A. Kamra, A. Kaushik, , K. Bala, and N. Rani, Biosorption of Cr(VI) by immobilized biomass oftwo indigenous strains of cyanobacteria isolated from metal contaminated soil, J.Haz.mat.148 (1)2007, 383-386.

[33]. P. Vauchel, K. Leroux, R. Kaas, A. Arhaliass, R. Baron, and J. Legrand, Kinetics modeling of alginate alkaline extraction from Laminariadigitata. Bioresource Technology, 100, 2009, 1291-1296.

[34]. F. Lai, G. Loy, M. Manconi, L. M. Manca, and A. M. Fadda, Artemisiaarborescens 1 essential oil loaded beads: Preparation and Characterization. AAPS Pharm Sci Tech, 8, 2007,E126-E132.

[35]. http://commons.wikimedia.org/wiki/File:Calcium_alginate_skeletal.svg

[36]. S.K.Saxena, First draft prepared by (C) FAO 2004 on POLYVINYL ALCOHOL (PVA), Chemical and Technical Assessment, 61st JECF

[37]. C. R. Nuttelman, D. J. Mortisen, S. M. Henry, and K. S. Anseth, Attachment of fibronectin to poly(vinyl alcohol) hydrogels promotes NIH3T3 cell adhesion, proliferation, and migration. Journal of Biomedical Materials Research, 57, 2001,217-223.

[38]. C. M. Hassan, and N. A. Peppas, Structure and applications of poly(vinyl alcohol) hydrogels produced by conventional crosslinking or by freezing/thawing methods. Advances in Polymer Science, 153, 2000,37-65.

[39]. D. Bezbradica, G. Matic, B. Obradovic, V. Nedovic, I. Leskosek-Cukalovic, and B. Bugarski, Immobilization of brewing yeast in PVA/alginate micro beads using electrostatic droplet generation. HemijskaIndustrija, 58, 2004, 118-120. 
[40]. Z.N. Lai, Y.D. Cui, and Z.Q. Yan, Research on oxygen permeability of PVA-alginate-active carbon copolymer hydrogel. Mater Rev (in Chinese). 22, 2008, 152-155.

[41]. http://en.wikipedia.org/wiki/Glutaraldehyde

[42]. S. Rengaraj, Seung-Hyeon Moon, Kinetics of adsorption of Co(II) removalfrom water andwastewater by ion exchange resins. Water Research 36, 2002, 1783-1793

[43]. H. Freundlich, and W. J. Helle, Ubber die adsorption in Lusungen, j. of American Chemical society, 61, $1939,2-28$.

[44]. N. Saifuddin and A.Z. Raziah, Removal of heavy metals from industrial effluent using Saccharomyces Cerevisiae(Baker's Yeast) immobilised in chitosan/lignosuphonate matrix. Journal of Applied Science and Research. 3(12), 2007, $2091-2099$.

[45]. M.A. Javed, H.N. Bhatti, M.A. Hanif and R. Nadeem, Kinetic and equilibrium modeling of Pb(II) and Co(II) sorption onto rose waste biomass. Separation Science and Technology. 42, 2007, 3641-3656.

[46]. M. Riaz, R. Nadeem, M.A. Hanif, T.M. Ansari and K.U. Rehman, Pb(II) biosorption from hazardous aqueous streams using Gossypiumhirsutum(Cotton) waste biomass. Journal of Hazardous Materials. 161, 2009, 88-94.

[47]. K. Bala, A. Kaushik, and C. P. Kaushik, Response surface methodlogical approach for optimizing removal of Cr(VI) from aqueous solution using immobilized caynobactreium, Chemical engg. J.,126, 2006, 147-153.

[48]. N., Akhtar, M., Iqbal, S.I. Zafar, and J. Iqbal,Biosorption characteristics of unicellular greenalgaChlorella sorokinianaimmobilized in loofa sponge for removal of Cr(III), J. of EnvironmentalSciences, 20, 2008,231-239.

[49]. K.Mohanty, M.Jha, B.C. Meikap, and M.N. Biswas, Biosorption of Cr(VI) from aqueoussolution by Eichhorniacrassipes. Chem. Eng.J.,117, 2006, 71-77.

[50]. M., Viswanadham, N. Sriamula, and M.C.Adharvana, Removal of Ni(II) and Zn(II) ions by usinga biopolymer chitin. Indian J. Environ. Health,44, 2000,78-81.

[51]. R., Saravanane, T. Sundararajan, and S.Sivamurthyreddy, Efficiency of chemically modified lowcost adsorbents for the removal of heavy metals from wastewater: a comparative study, Indian J.Environ. Prot., 20, 2002, 515-520.

[52]. R., Kumar, N.R., Bishnoi, Garima and K.Bishnoi, Biosorptionof Cr(VI) from aqueous solutionand electroplating wastewater using fungal biomass. Chemical Eng.J.,135, 2008, 202-208.

[53]. F.A., Abu, M.H., El, F. Benyahia, and I. Ashour, Biosorption ofnickel on blank alginate beads, free and immobilized algal cells, Proc. Biochem., 39, 2004, 1767-1773.

[54]. N., Rangsayatorn, P., Pokethitiyook, E.S. Upatham, and G.R. Lanza, Cd biosorption by cells of spirulinaplatensististr 8217 immobilized in alginate and silica gel, Environment Int.,30, 2004,(57 63).

[55]. L.C. Ajjabi, and L. Chouba,Biosorption of $\mathrm{Cu}^{2+}$ and $\mathrm{Zn}^{2+}$ from aqueous solutions by driedmarine green macroalgaChaetomorphalinum, J. of Environmental Management, 90,2009,3485-3489.

[56]. G.W, Granham, G.A. Codd, and G.M. Gadd, Accumulation of cobalt, zinc and manganese by theesturine green microalga Chlorellasalinaimmobilized in alginate microbeads. Environ. Sci. Tech.,26, 1992,1764-1770.

[57]. A. Ozer and D. Ozer, Comparative study of the biosorption of $\mathrm{Pb}$ (II), $\mathrm{Ni}$ (II) and $\mathrm{Cr}$ (VI) ions onto S. cerevisiae: determination of biosorption heats. Journal of Hazardous Materials. 100, 2003, 219-229.

[58]. R. Nadeem, M.A. Hanif, F. Shaheen, S. Perveen, M.N. Zafar and T. Iqbal. Physical and modification of distillery sludge for Pb(II) biosorption. Journal of Hazardous Materials. 150, 2007, 335-342.

[59]. A. Sari, M. Tuzen, O.D. Uluuozlu and M. Soylak, Biosorption of Pb(II) and Ni(II) from aqueoussolution by lichen (Cladoniafrrcata) biomass. Biochemical Engineering Journal. 37, 2007, 151-158.

[60]. S., Mor, R. Khaiwal, and N.R. Bishnoi, Adsorption of chromium from aqueous solution byactivated alumina and activated charcoal, Bioresour. Technol.,8, 2006,954-957.

[61]. D.Kratochvil, P. Pimentel, and B.Volesky, Removal of trivalent and hexavalent chromium byseaweedbiosorbent. Environ.Sci. Technol., 32, 1998, 2693-2698.

[62]. Y.S.Yun, D. Park, J.M. Park, and B.Volesky, Biosorption of trivalent chromium on the brownseaweed biomass. Environ.Sci. Technol., 35, 2001, 4353-4358.

[63]. J.L.Gardea-Torresdey, K.J.Tiemann, J.H. Gonzalez, O.Rodriguez, and G.Gamez,Phytofiltration of Hazardous Cadmium, Chromium, Lead, and Zinc Ions by Biomass of MedicagoSativa (Alfalfa), J. Haz..Mat., 57, 1998, 29-39.

[64]. N. Tiwari, P.Vasudevan, and B.K.Guha, Study on biosorption of Cr (VI) by Mucorhiemalis. J.Biochem.Engg., 23, $2005,185-192$.

[65]. D.D.M. Dacera, and S. Babel, Removal of heavy metals from contaminated sewage sludge using Aspergillusniger fermented raw liquid from pineapple wastes.Biores. Technol., 99(6), 2008, 1682-1689.

[66]. R. Kumar, R. Singh, N. Kumar, K.Bishnoi, and N.R.Bishnoi, Biosorption process for removaof Cr (VI), Ni (II) and Zn (II) ions by immobilized bacterial biomass sp. bacillus brevis.Chemical Eng. J.,146, 2009, 401-407.

[67]. P. Kaewsarn, and Q.Yu, Cadmium(II) removal from aqueous solutions by pretreated biomass ofmarine alga Padina sp.Environ. Pollut. 112, 2001, 209-213.

[68]. K.V. Kumar, V. Ramamurthi, and S.Sivanesan, Biosorption of Malachite Green a Cationic DyeontoPithophora sp., a Fresh Water Algae, Dyes and Pigm., 69, 2006, 74.

[69]. V.K Gupta, and A.Rastogi, Biosorption of lead from aqueous solutions by green algae Spirogyraspecies: kinetics and equilibrium studies. J. Haz. Mat.,152, 2008 a, 407-414.

[70]. V.K Gupta, and A. Rastogi, Sorption and desorption studies of chromium(VI) from nonviablecyanobacteriumNostocmuscorum biomass. J. Haz. Mat., 154 (1-3), 2008b, 347-354.

[71]. V.K. Gupta, and A. Rastogi, Biosorption of lead from aqueous solutions by non living algalbiomassOedogenium sp. and Nostoc sp. - a comparative study. Colloids Surf. B: Biointerfaces, 64(2), 2008c, 170-178.

[72]. A. Sari, and M.Tuzen, Biosorption of $\mathrm{Pb}(\mathrm{II})$ and $\mathrm{Cd}(\mathrm{II})$ from aqueous solution using green alga Ulvalactuca biomass.J.Haz.mat.,152 (1), 2008, 302-308.

[73]. M.Malakootian, A. Almasi, and H. Hossaini, Pb and Co removal from paint industries effluentusing wood ash. Int.J. Environ. Sci. Tech., 5 (2), 2008, 217-222.

[74]. T. Jose, and Q.Yu, Biosorption of Lead(II) and copper(II) from aqueous solutions by pre-treatedbiomass of Australian marine algae, Bioresource Technol., 69, 1999, 223-229.

[75]. E.Yalçın, K. Çavus,og־lu, M. Maras, and M. Bıyıkog־lu, Biosorption of Lead (II) and Copper(II) Metal Ions on Cladophoraglomerata(L.) Kütz. (Chlorophyta) Algae: Effect of Algal SurfaceModification, ActaChim.Slov., 55: $2008,228-232$.

[76]. W. Xuejiang, X. Siqing, C. Ling, Z. Jianfu, C. Jeanmarc and N.J. Renault.Biosorption of cadmium(II) and lead(II) ions from aqueous solution onto dried activated sluge. Journal of Environmental Science. 18(5), 2006, 840-844.

[77]. A. Zubair, H.N. Bhatti, M.A. Hanif and F. Shafqat. Kinetic And Equilibrium Modeling forCr(III) and Cr(VI) Removal from Aqueous Solutions by Citrus reticulate Waste Biomass. Water, Airand Soil Pollution. 191, 2008, 305-318. 
[78]. R. Kumar, N. R. Bishnoi, Garima, K. Bishnoi, Biosorption of chromium(VI) from aqueous solution and electroplating wastewater using fungal biomass, Chemical Engineering Journal,135 (3), 2008, 202-208

[79]. N.R., Bishnoi, R., Kumar, S. Kumar, and S. Rani, Biosorption of Cr (III) from aqueous solutionusing algal biomass Spirogyra spp., J. Haz. Mat., 145, 2007,142-147.

[80]. B. Volesky, Sorption and Biosorption, (B V sorbex Inc., Montreal, St. lambert, Quebec, Canada,2003)

[81]. B. E. Reed and M. R. Matsumoto, Modeling cadmium adsorption by activated carbon using the Langmuir and Freundlich isotherm expressions.Separation Science and Technology, 28, (13-14) 1993, 2179-2195,

[82]. G McKay, H.S. Blair, and J.R. Garden, Adsorption of dyes on chitin. 1. Equilibrium studies. J ApplPolymSci 27, $1982,3043-57$.

[83]. G. McKay, M.S. Otterburn, and A.G. Sweeney, The removal of colour from effluent using various adsorbents. III. Silica: rate processes, Water Research, 14( 1), 1980,15-20.

[84]. A. Ozer and H. B. Pirinc $c_{s} c_{s}$ i, The adsorption of Cd(II) ions on sulphuric acid-treated wheat bran, Journal of Hazardous Materials, 137( 2), 2006, 849-855.

[85]. Y. S. Ho, Removal of copper ions from aqueous solution by tree fern, Water Research, 37, 2003, 2323-2330.

[86]. B. Subramanyam, and A. Das, Linearized and non-linearized isotherm models comparative study on adsorption of aqueous phenol solution in soil.Environ. Sci. Tech., 6, 2009, 633-640. 